\title{
Indicator Properties of the Paper-Bill Spread: Lessons from Recent Experience
}

\section{Citation}

Friedman, Benjamin M. and Kenneth N. Kuttner. 1998. Indicator properties of the paper-bill spread: Lessons from recent experience. Review of Economics and Statistics 80(1): 34-44.

\section{Published Version}

doi:10.1162/003465398557311

\section{Permanent link}

http://nrs.harvard.edu/urn-3:HUL.InstRepos:4554251

\section{Terms of Use}

This article was downloaded from Harvard University's DASH repository, and is made available under the terms and conditions applicable to Other Posted Material, as set forth at http:// nrs.harvard.edu/urn-3:HUL.InstRepos:dash.current.terms-of-use\#LAA

\section{Share Your Story}

The Harvard community has made this article openly available.

Please share how this access benefits you. Submit a story.

Accessibility 


\title{
INDICATOR PROPERTIES OF THE PAPER-BILL SPREAD: LESSONS FROM RECENT EXPERIENCE
}

\author{
Benjamin M. Friedman and Kenneth N. Kuttner*
}

\begin{abstract}
A feature of U.S. postwar business cycle experience that is by now widely documented is the tendency of the spread between the respective interest rates on commercial paper and Treasury bills to widen shortly before the onset of recessions. By contrast, the paper-bill spread did not anticipate the 1990-1991 recession. Empirical work presented in this paper supports two (not mutually exclusive) explanations for this departure from past experience. First, at least part of the paper-bill spread's predictive content with respect to business cycle fluctuations stems from its role as an indicator of monetary policy, but the 1990-1991 recession was unusual in postwar U.S. experience in not being immediately precipitated by tight monetary policy. Second, movements of the spread during the few years just prior to the 1990-1991 recession were strongly influenced by changes in the relative quantities of commercial paper, bank CDs, and Treasury bills that occurred for reasons unrelated to the business cycle. This latter finding in particular sheds light on the important role of imperfect substitutability of different short-term debt instruments in investors' portfolios, and highlights the burdens associated with using relative interest rate relationships as business cycle indicators.
\end{abstract}

\section{Introduction}

$\mathrm{N}$ UMEROUS researchers writing in recent years have documented the information content, with respect to subsequent fluctuations in U.S. real output, of the difference between the respective interest rates on commercial paper and Treasury bills. ${ }^{1}$ As figure 1 shows, the paper-bill spread tends to widen markedly about 6 months before the onset of a business recession (or other slowdown in real economic activity). Since 1959 the spread has averaged 88 basis points during all 6-month periods immediately prior to recessions and 103 basis points during recessions, versus only 43 basis points in all other months. ${ }^{2}$ Various researchers have shown that this relationship has historically been highly significant in standard regression analysis (more or less regardless of what other regressors the equation includes), in Grangertype "causality" tests, and in variance decompositions based on vector autoregressions. By now familiar reasons why the paper-bill spread would widen in anticipation of business downturns include the possibility that a widening spread is (1) an indicator of tight monetary policy, (2) a reflection of

Received for publication February 8, 1996. Revision accepted for publication February 10, 1997.

* Harvard University and Federal Reserve Bank of New York, respectively.

The authors are grateful to Joel Krueger for research assistance; to Thomas Cosimano, John Golob, Paul Samuelson, Mark Watson, and numerous other colleagues for helpful comments and discussions; to James Stock and two anonymous referees for useful criticism of an earlier draft; and to the G.E. Foundation and the Harvard Program for Financial Research for research support. The opinions expressed here are the authors' own; in particular, they do not necessarily reflect official positions of the Federal Reserve Bank of New York.

${ }^{1}$ See, for example, Stock and Watson (1989), Bernanke (1990), Davis and Henry (1991), Friedman and Kuttner (1992, 1993a), Huh (1993), Lahiri and Wang (1994), Miyao (1994), Estrella and Mishkin (1996), and Ferderer et al. (1998).

2 The sample used here is January 1959 through September 1996. The empirical work presented throughout this paper relies on 6-month maturities for both instruments. Corresponding results based on 3-month maturities (available from the authors on request) are highly similar. anticipations of business bankruptcies, and (3) a result of corporations' growing cash requirements as the business expansion nears its peak.

By contrast, the paper-bill spread failed completely to anticipate the 1990-1991 recession. As figure 1 also shows, the spread fluctuated at levels normally predictive of recession from mid-1987 to mid-1989, then narrowed sufficiently to eliminate any indication of likely recession by the beginning of 1990, and did not noticeably begin to widen again until after the recession had begun in July 1990. Since then the behavior of the paper-bill spread has been more consistent with prior patterns. The spread declined sharply just as the recession ended in March 1991, and from then through late 1996 (the time of writing) it remained at narrow, clearly nonrecessionary levels.

The failure of the paper-bill spread to anticipate the 1990-1991 recession was a failure shared by essentially all familiar monetary and financial indicator variables. For example, growth of the M2 money stock peaked in late 1986 and by year-end 1987 had slowed to rates that historically would have predicted recession. Growth of M2 revived in 1988, faltered again in early 1989, but then revived even more strongly from mid-1989 onward, so that by the time the recession began, at midyear 1990, M2 also was giving just the opposite signal. The slope of the yield curve, another familiar business cycle indicator, flattened in 1988 and throughout 1989 in a way that often anticipates recessions, but by early 1990 the yield curve began to steepen again while the recession was still half a year away. Some researchers have concluded, in part on the basis of this universal failure of standard indicator variables drawn from the financial side of the economy, that the 1990-1991 recession was unique in its origins. ${ }^{3}$

The object of this paper is to see what conclusions can be drawn from a closer look at the failure of the paper-bill spread in particular during this episode. To anticipate, the results of this analysis offer some support for the claim that the 1990-1991 recession was highly unusual in post-World War II U.S. experience, at least in not being immediately precipitated by tight monetary policy. But as previous research has shown (and results reported here reaffirm), the predictive content of the paper-bill spread with respect to real output apart from the 1990-1991 experience has not been solely a matter of the spread's role as an indicator of monetary policy. Hence merely saying that monetary policy was not the cause of the recession is not sufficient to explain the aberrant movement of the paper-bill spread. To that more specific end, the results presented here point also to developments in both fiscal policy and debt management policy, as well as in the banking system, during the late

\footnotetext{
${ }^{3}$ See, for example, Perry and Schultze (1993).
} 
Figure 1.-SiX-Month PaPer-BiLl SpRead, January 1959 TO SEPTEMBER 1996 (RECESSIONS SHADED)

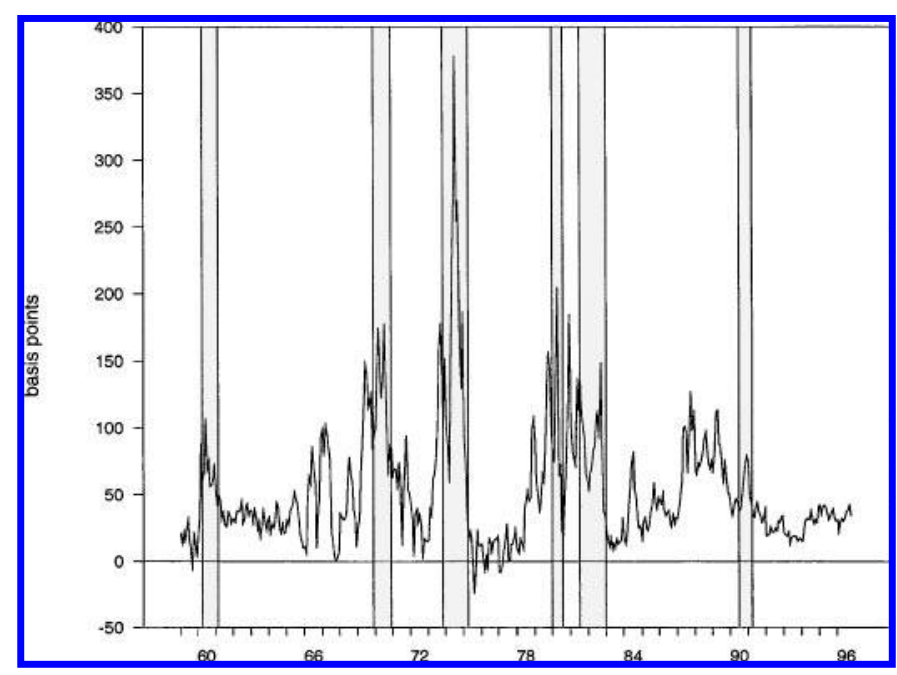

1980s. Pursuing this particular line of analysis clarifies the key role of imperfect substitutability of commercial paper and Treasury bills in investors' portfolios, and highlights the burdens that such imperfect substitutability places on the use of this or any similar interest rate spread variable as a business cycle indicator.

\section{Potential Explanations for the Failure}

Why might the paper-bill spread, contrary to previous experience, have failed to anticipate the 1990-1991 business recession? At least three different explanations are plausible, corresponding in turn to three different hypotheses about why the spread is normally related to fluctuations of real output in the first place. In addition, a fourth potential explanation, bearing on the extent to which investors regard commercial paper and Treasury bills as portfolio substitutes, also merits investigation.

\section{A. Absence of Tight Monetary Policy}

First, if fluctuations of the paper-bill spread mostly indicate changes in the stance of monetary policy, but tight monetary policy did not play a significant role in bringing about the 1990-1991 recession, there is no reason why the spread should have widened in advance of this decline in output. Several researchers writing on this subject have worked out models in which a widening paper-bill spread is an indicator of tight monetary policy. ${ }^{4}$ In brief, the central idea is that restricting the growth of bank reserves causes banks to be less forthcoming in granting loans, which in turn drives would-be borrowers to seek funds in the commercial paper market instead. The resulting increase in commercial paper issuance would then raise the paper rate, relative to the Treasury bill rate, either because the marginal borrowers

\footnotetext{
${ }^{4}$ See, for example, Bernanke (1990), Kuttner (1992), Friedman and Kuttner (1993a), Kashyap et al. (1993), and Calomiris et al. (1994).
}

driven out of the banking system are on average smaller and less creditworthy than borrowers already active in the commercial paper market (so that the average liquidity and quality of outstanding paper deteriorate) or, given reasonable restrictions on the relevant asset supply and demand elasticities, simply because investors regard paper and bills as imperfect portfolio substitutes (so that relative outstanding quantitites affect relative required returns). ${ }^{5}$

Although the subject remains one of contention, many economists have documented the key role of tight monetary policy-however defined and measured-in bringing about most if not all U.S. business downturns. ${ }^{6}$ To the extent that that is so, and that tight monetary policy also widens the paper-bill spread, movements in the spread would naturally contain systematic information about subsequent movements in real output. But in the case of a decline in output that occurred independently of tight money-for example, because of an adverse supply shock, or tight fiscal policy, or a fall in consumer confidence-no such relationship would appear.

\section{B. Inaccurate Market Perceptions of Default Risk}

A second potential source of the usual predictive power of the paper-bill spread with respect to real output is the spread's role as an indicator of market perceptions of the likelihood of business bankruptcy and default. Unlike the U.S. Treasury, private firms can and sometimes do default on their debts, and commercial paper is by definition an unsecured obligation. Moreover, the incidence of corporate bankruptcy and default fluctuates in a pronounced way with the business cycle. If investors in commercial paper perceive specific signs of default risk at individual companies, or if they simply believe on other grounds that a business downturn is imminent and hence infer that the probability of default by any given company is greater, they will therefore demand a higher stated interest rate on paper relative to default-free bills.

To the extent that investors' expectations in either of these regards have at least some systematic tendency to be correct, the paper-bill spread will therefore widen in advance of business downturns. (Further, to the extent that investors base their expectations on assessments of individual firms' prospects, the spread serves as a summary statistic for disparate sources of information that may be difficult to capture compactly in standard business indicators.) Tending to be correct on average is not the same as being correct all the time, however. Expectations of recession and consequent default risk that fail to materialize will widen the paper-bill

\footnotetext{
${ }^{5}$ Friedman and Kuttner (1993b) also offered a third potential reason for tight monetary policy to widen the spread, based on the difference in how "relationship" markets such as the bank loan market and "arm's length" markets such as the commercial paper market allocate the noninterest costs of borrowing.

${ }^{6}$ The classic historical reference is Friedman and Schwartz (1963). Prominent examples of the more recent literature include Romer and Romer (1989) and Bernanke and Blinder (1992). For an opposing point of view see, for example, Prescott (1986).
} 
spread even though no business downturn occurs subsequently. Conversely, confidence in the business outlook will keep the spread narrow even if that confidence subsequently proves mistaken. Indeed, if changing perceptions of default risk were the only reason why variation in the spread on average contains information about future output fluctuations, the failure of the spread to widen before the 19901991 recession would simply mean that investors failed to see the downturn coming.

\section{Changes in Asset Quantities Unrelated to the Business Cycle}

Third, to the extent that commercial paper and Treasury bills are imperfect substitutes in investors' portfolios, so that changes in the relative outstanding supplies of these two instruments bring about changes in their relative expected returns, those relative interest rate movements will be connected to business cycle fluctuations only if the underlying movements in the relative quantities are themselves a consequence of business cycle developments. Investors in U.S. markets plausibly treat commercial paper and Treasury bills as imperfect substitutes for several reasons, including differing state-level income tax treatment of interest earned (interest from bills is exempt), different liquidity (much greater for bills), and different default risk (zero for bills). ${ }^{7}$ All other things being equal, therefore, when factors related to the business cycle move the quantity of commercial paper relative to that of Treasury bills-for example, when tight monetary policy drives borrowers out of the banking system, or when slowing sales require firms to raise more cash to finance their inventories - the resulting movements in the paper-bill spread bear a systematic relationship to movements in real output.

By contrast, factors unrelated to the business cycle can also cause the relative quantities of commercial paper and Treasury bills to vary, and these changes too imply movements in relative interest rates. For example, the Treasury's debt management policy determines its reliance on bills (that is, discounted obligations maturing in one year or less) versus longer term coupon-bearing securities in financing a given U.S. Government deficit. State and local governments buy Treasury securities to "prerefund" their own outstanding obligations, thereby reducing the market supply available to private investors. Foreign central banks that intervene to support the dollar exchange rate are free in principle to hold the dollars they acquire in any form they choose, but in practice the proceeds of such intervention go almost entirely into Treasury bills, again reducing the market supply available to private investors. The repeated finding that the paper-bill spread bears a highly significant relationship to business cycle fluctuations presumably means that

\footnotetext{
${ }^{7}$ Cook (1981) was among the first to emphasize the imperfect substitutability of commercial paper and Treasury bills.
}

"noise" in the spread due to such idiosyncratic movements in relative asset quantitites is mostly small compared to movements that are systematically connected to the business cycle. But it is also possible that sufficiently large idiosyncratic movements may dominate the movement of the spread over any given period, and they may have done so in the episode in question here.

\section{Increasing Substitutability}

Finally, it is also possible that the evolution of the U.S. financial markets over time has rendered commercial paper and Treasury bills more nearly perfect substitutes, perhaps to the point that the spread between these two instruments' respective returns no longer bears a systematic relationship to variations in their respective quantities (or, for that matter, to anything else connected to the business cycle). ${ }^{8}$ For example, the more the markets are dominated by tax-exempt institutional investors, the less important is the differential tax treatment of paper and bills. As the commercial paper market has grown over the years ( $\$ 675$ billion outstanding as of year-end 1995), the liquidity of the typical issue may have improved. And with but few actual defaults, at least among prime-rated issuers, investors' perception of the default risk on commercial paper may have diminished. (Further, most issuers today back up their outstanding commercial paper with lines of credit at banks, although these arrangements do not provide full default protection because the bank agreements typically include a "no material changes" clause.)

One immediate implication of closer substitutability between commercial paper and Treasury bills would be a narrower average spread between their two respective interest rates. As figure 1 immediately shows, there is no evidence that such systematic narrowing occurred in the period leading up to the 1990-1991 recession. (To the contrary, one part of the puzzle to be explained is that the spread was so wide from mid-1987 to mid-1989.) A further implication, however, is that the spread between returns on two assets that are increasingly close substitutes would exhibit fluctuations that were increasingly just random noise, rather than reflections of the business cycle or other systematic influences. In particular, changing relative asset supplies would have a smaller, if not zero, effect on the spread. This second implication of the increasingly perfect substitutability hypothesis bears empirical investigation.

\section{A Systematic Look at the Recent Experience}

The solid lines in the four panels of figure 2 display the monthly movements of the paper-bill spread together with three financial variables intended to capture the three main

\footnotetext{
${ }^{8}$ Kashyap et al. (1993) and Thoma and Gray (1994) have argued along these lines.
} 
Figure 2.-Key Financial Variables and Their InNovations

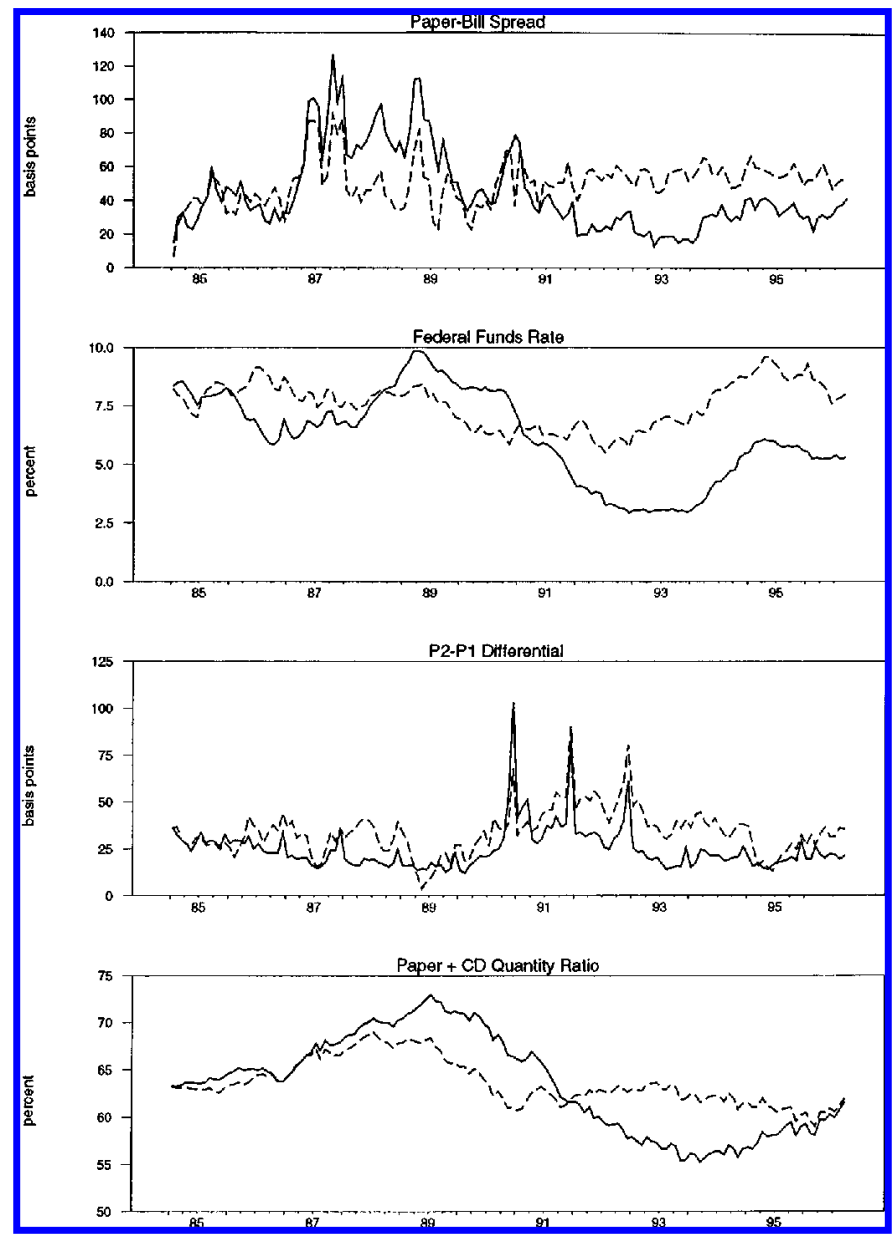

The solid lines show the actual movements of the financial variables included in the VAR described in the text. The dashed lines show the contributions of each series' "own" innovations derived from the same VAR.

factors to which researchers have pointed in efforts to account for the usual systematic relationship between the spread and real output. The paper-bill spread itself is in the top panel. The federal funds rate, used as an indicator of monetary policy, is in the second panel. ${ }^{9}$ Next is the interest rate differential between commercial paper issues rated $\mathrm{P} 2$ (the second highest category) and P1 (the highest) by Moody's Investors Service, used as a measure of perceived default risk. The bottom panel shows the ratio of the volume of outstanding commercial paper plus bank (and thrift) certificates of deposit to this sum plus the volume of outstanding Treasury bills, used to measure relative asset quantities. Each panel displays monthly data beginning in 1985 , a date comfortably in advance of the puzzling episode under investigation here.

The inclusion of bank CDs in both numerator and denominator of the asset quantity ratio reflects the assumption that investors treat $\mathrm{CDs}$ and commercial paper as

\footnotetext{
${ }^{9}$ Bernanke (1990), Bernanke and Blinder (1992), and others have used the federal funds rate as a monetary policy indicator.
}

(essentially) perfect substitutes for one another, and neither as a perfect substitute for Treasury bills, in their portfolios-an assumption that is plausible on both a priori and empirical grounds. Bank CDs are comparable to commercial paper, and correspondingly different from Treasury bills, in tax treatment, default risk, and liquidity. Not only is the average CD-paper spread much smaller than the average paper-bill spread (13 basis points versus 64 ), but the correlation between the CD-bill spread and the paper-bill spread is 0.97 (versus 0.78 between the CD-bill spread and the CD-paper spread, and only 0.60 between the CD-paper spread and the paper-bill spread). ${ }^{10}$ In addition, the CD-bill spread, like the paper-bill spread, is highly significant in standard equations for real output (even in the presence of the federal funds rate), while the CD-paper spread is not. ${ }^{11}$

Did the movements of the paper-bill spread in the period leading up to and including the 1990-1991 recession mostly reflect movements in the federal funds rate, in perceived default risk, or in relative asset quantities? Or were the spread's movements during this period mostly unrelated to these three financial variables (and the channels of economic influence that they represent)?

The dashed lines in the four panels of figure 2 begin to address this question by plotting the respective movement of the spread and each of these other variables that is attributed to the variable's "own" innovations in a six-variable vector autoregression including growth of industrial production, growth of the producer price index, the other three financial variables as shown, and the paper-bill spread itself, orthogonalized in that order. ${ }^{12}$ Following previous researchers, this ordering implies that the central bank may take account of current-month movements of output and prices in setting monetary policy (the federal funds rate), but that monetary policy does not affect either output or prices within the month. ${ }^{13}$ It also implies that monetary policy may affect any or all of the other three financial variables within the month, but not vice versa. Finally, ordering the paper-bill spread last means that the spread may respond within the month to any of the other real- or financial-sector variables, but not vice versa. The vector autoregression is estimated using

\footnotetext{
${ }^{10}$ Values are based on monthly data for January 1975 through September 1996 for the 3-month paper, bill, and CD rates. (No 6-month CD rates are available.) Especially for recent years, it would also be plausible to include U.S. holdings of Eurodollar CDs and Eurodollar commercial paper as another close substitute for U.S. commercial paper. Outstanding amounts of Euro CDs and Euro paper are still small, however, compared to U.S. bills, paper, and CDs.

${ }^{11}$ The treatment of commercial paper and bank (and thrift) CDs as perfect substitutes follows Friedman and Kuttner (1993b); see there for further supporting evidence.

12 The industrial production and PPI series both enter the autoregression in log-differenced form; the four financial variables enter as levels. The industrial production data are seasonally adjusted; data for all other variables are not.

${ }^{13}$ See, for example, Bernanke and Blinder (1992) and Christiano et al (1996).
} 
monthly data for January 1976 to September 1996, with six lags on each variable. ${ }^{14,15}$

Several relevant conclusions emerge from this comparison of actual fluctuations to the corresponding innovations. First, part of the anomalous movement in the paper-bill spread during 1987-1990 — but importantly, for purposes of this paper's analysis, only part-is left as unexplained in the sense of being attributed to the spread's "own" innovations. From the low point in September 1986 to the high point in October 1987 (the month of the stock market crash), the spread widened by 101 basis points. The corresponding movement contributed by the spread's "own" innovations was just 46 basis points, with most of that occurring in the month of the crash, and by January 1988 the "own" component was already back to where it had been in September 1986. The spread narrowed by 79 basis points between April 1989 and February 1990, and in this case the corresponding movement in the "own" component was (minus) 55 basis points. In other words, part, but only a part, of the movement in the spread during this period that ran so counter to prior business cycle experience was unexplainable noise. The rest can be attributed to systematic influences, including the three other financial variables represented in this system.

Which ones? Not monetary policy, at least not according to this analysis. As the second panel of figure 2 shows, the (nominal) federal funds rate was low in 1987 when the spread was puzzlingly wide, and the funds rate was higher in 1989 when the spread was narrowing. The corresponding innovations in the federal funds rate tell qualitatively the same story, but here the main message is that quantitatively monetary policy was simply not very active. In contrast to the usual finding that the historically high levels of the funds rate during the 1979-1981 episodes of tight money under Paul Volcker corresponded to large positive funds rate innovations, here the "own" component of the funds rate changed little during the several years leading up to July 1990, and what change took place was mostly downward. This perspective on the more recent experience provides support for the familiar claim that the 1990-1991 recession was unusual in not being proximately due to unusually tight monetary policy. ${ }^{16}$

\footnotetext{
${ }^{14}$ The earliest possible sample starting date would be January 1974, the beginning of the data series for the Moody's P2-P1 quality differential. The reason for starting in January 1976 instead is to eliminate any suggestion that the estimated relation between real output and the paper-bill spread is a spurious result due to the sharp spike in the spread in 1974 (see again figure 1). Thoma and Gray (1994), for example, have argued along those lines, but in fact results showing that the paper-bill spread has predictive content with respect to real output are highly robust to eliminating the 1974 spike period.

${ }^{15}$ Results based on an alternative system with six lags on some variables and twelve on others, determined according to a series of goodness-of-fit criteria, were virtually indistinguishable from those reported here.

${ }^{16}$ As is well known, the use of vector autoregression innovations-for interest rates, monetary aggregates, or any other variable — as an indicator of monetary policy necessarily excludes any systematic (for example, countercyclical) component of policy; see, for example, the discussion in Sims (1992), Poole (1994), and Friedman (1996). For this reason it is
}

How about the other two financial indicators? ${ }^{17}$ Changes in perceived default risk also appear to have played only a limited role during the period leading up to the 1990-1991 recession. Apart from a small but regular spike each December, presumably reflecting "window dressing" sales by institutions eager to show only top-rated paper on their year-end balance sheets, the P2-P1 quality differential followed a smooth, slightly downward trend from the middle 1980s until just a few months before the recession began. (The larger window dressing effect in 1990, 1991, and 1992 probably reflects the Securities and Exchange Commission's action limiting money market funds' holdings of commercial paper with less than a P1 rating.) The component of the quality differential attributable to that variable's "own" innovations showed somewhat closer correspondence with movements in the paper-bill spreadespecially the narrowing in mid-1987 and again in early 1989 - but even here the correspondence is hardly close.

By contrast, the ratio of commercial paper plus CDs to the broader sum also including Treasury bills fluctuated widely during this period, and especially during 1987-1990 much of that fluctuation was attributable to this ratio's "own" innovations rather than to the other variables included in this analysis. The sustained increase in the quantity ratio during 1986-1989 (a period when many U.S. businesses were greatly increasing their debt loads through leveraged buyouts, stock repurchases, and debt-financed acquisitions) was in large part the cumulated effect of positive "own" innovations, while a substantial part of the even more rapid decline of the quantity ratio during 1990-1993 (the era of widespread "deleveraging") was the cumulative effect of negative "own" innovations.

At least qualitatively, the bulge in the quantity ratio during 1987-1988 would have caused the paper-bill interest rate spread to widen, and the decline in the quantity ratio from mid-1989 on would have caused the paper-bill spread to narrow. Moreover, to the extent that these movements in the quantity ratio were the effect of this variable's "own" innovations, not explained by the other variables in the system-importantly including real output and prices, as well as the level of interest rates-the resulting quantitydriven influences on the spread would have been unrelated to the business cycle. In particular, in this case the increase in the quantity ratio during 1986-1989 was therefore not primarily a reflection of tight monetary policy driving borrowers from the banks into the commercial paper market, or of the usual business cycle effects on corporate cash requirements, nor was the decline in the quantity ratio after mid-1989 due to such usual cyclical factors either.

\footnotetext{
important to examine both the innovations and the movements of the funds rate itself, as is done here.

${ }^{17}$ The suggestion that the paper-bill spread is exclusively a monetary policy indicator, as Bernanke (1990) and Kashyap et al. (1993) have proposed, is not supported by the data. For example, in the six-variable vector autoregression under study here, the federal funds rate together with output growth and inflation-and with these variables ordered firstaccounts for only $49 \%$ of the variance of the spread at a 6-month horizon.
} 
Figure 3.-Contributions of Key Financial Variables TO PAPER-BILl SPREAD

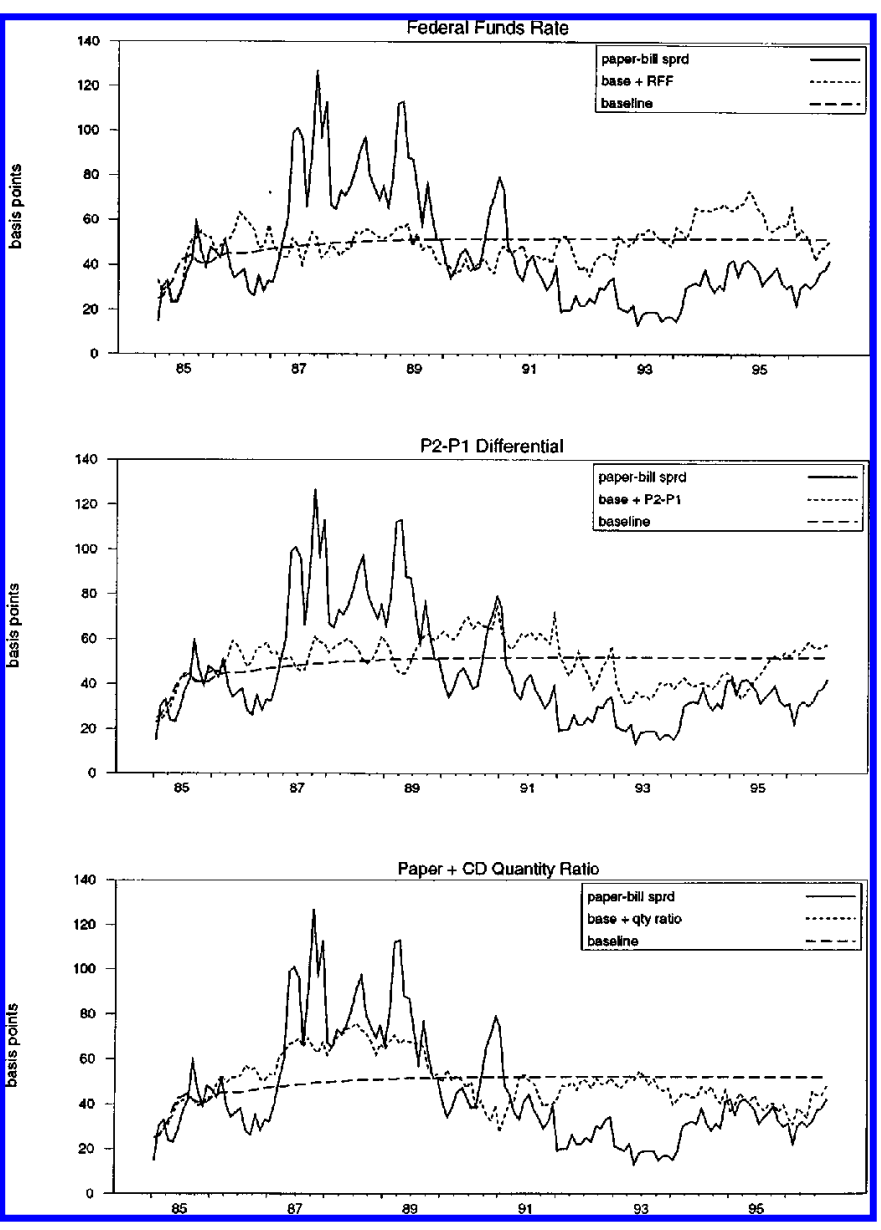

The solid lines show the actual movement of the paper-bill spread, and the dashed lines show the VAR baseline described in the text. The dotted lines show the effects of adding to the baseline the contribution of the innovations of each financial variable included in the VAR.

Figure 3 shows that these three sets of qualitative conclusions carry over to quantitative analysis. In each panel the solid line is the actual movement of the paper-bill spread during January 1985 to September 1996, and the dashed line is a corresponding baseline forecast generated by simulating forward the six-variable vector autoregression using data through the end of 1984 only. (These two lines are identical across all three panels in the figure.) The dotted line in each panel then shows the contribution to the paper-bill spread, measured around that baseline, of the estimated innovations corresponding to each in turn among the three other financial variables under study here.

Not surprisingly, given the results shown in figure 2, federal funds rate innovations played little if any role in accounting for the movement of the paper-bill spread during 1987-1990. Unlike in the Volcker period, for which an analogous exercise indicates not only large federal funds rate innovations but large effects of those innovations on the spread, in this most recent episode monetary policy seems not to have been much of a factor. Default risk innovations likewise played little part.
By contrast, the bottom panel of figure 3 shows that much of the widening of the paper-bill spread during 1987-1988 and the narrowing in 1989 and early 1990 is attributable to asset quantity innovations. Indeed, for the period of January 1987 through June 1990 (the last month before the recession began) the simple correlation between the actual spread and the value calculated as the baseline plus the effect of quantity ratio innovations is 0.74 . The cumulative contribution to the spread due to quantity ratio innovations rose rapidly from just 6 basis points in January 1987 to 21 basis points in July, fluctuated around that level throughout the next two years (the peak effect was 26 basis points in July 1988), and then declined abruptly back to 5 basis points in October 1989 and on to -25 basis points in January 1991. Moreover, the large and sustained positive influence on the spread due to quantity ratio innovations from early 1987 to mid-1988, and also the negative influence in late 1989 and throughout 1990, were highly unusual in historical context. Carrying out the analytical exercise underlying figure 3 for earlier periods (including the Volcker years) indicates no comparable effects.

\section{Focus on Relative Quantity Movements and Their Effects}

Why did the quantity of commercial paper and bank CDs grow so rapidly compared to the quantity of Treasury bills from early 1987 through mid-1989, only to go into reverse from then on? As figure 2 shows (see again the bottom panel), much of the movement of this quantity ratio throughout 1987-1990 represented historically large "own" innovations, not explainable by fluctuations in real output and prices, or in any of the other financial variables under study here. What happened?

Figure 4 shows that each of the three assets encompassed in this relationship-commercial paper, bank CDs, and Treasury bills-exhibited historically unusual movements

Figure 4.-Volumes of Selected Short-Term Debt InStruments OUTSTANDING, JANUARY 1967 TO SEPTEMBER 1996

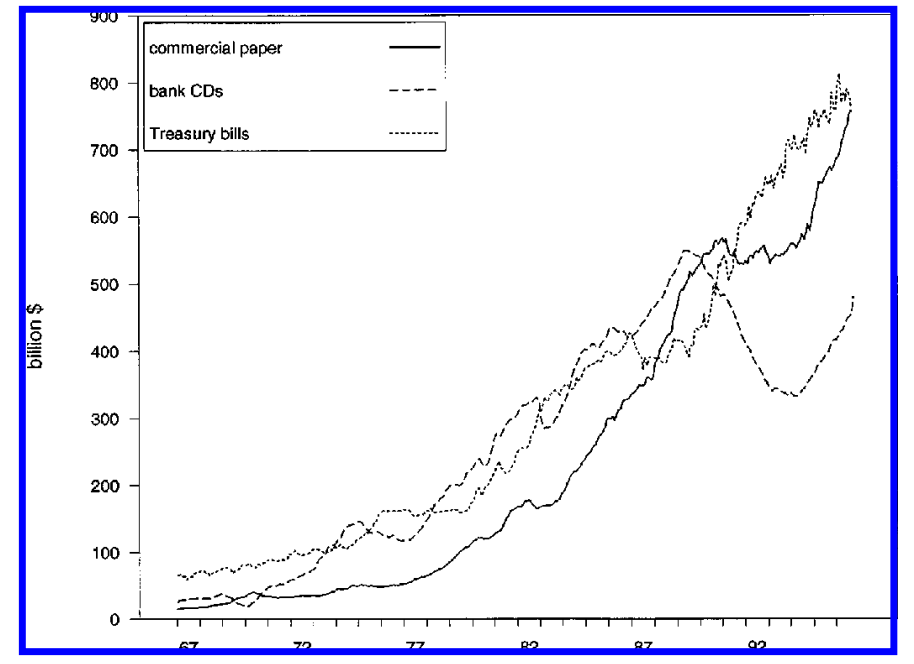


Table 1.-Federal Deficit, Debt Structure, and Foreign Holdings OF BILLS, 1984-1990

\begin{tabular}{cccccc}
\hline \hline Year & $\begin{array}{c}\text { Federal } \\
\text { Deficit }\end{array}$ & Bills & Notes & Bonds & $\begin{array}{c}\text { Foreign- } \\
\text { Owned } \\
\text { Bills }\end{array}$ \\
\hline 1984 & 185.4 & 374.4 & 705.1 & 167.9 & 122.1 \\
1985 & 212.3 & 399.9 & 812.5 & 211.1 & 125.6 \\
1986 & 221.2 & 426.7 & 927.5 & 249.8 & 162.4 \\
1987 & 149.8 & 389.5 & 1037.9 & 282.5 & 198.3 \\
1988 & 155.2 & 414.0 & 1083.6 & 308.9 & 234.7 \\
1989 & 153.5 & 430.6 & 1151.5 & 348.2 & 233.0 \\
1990 & 220.5 & 527.4 & 1265.2 & 388.2 & 247.5
\end{tabular}

Notes: Amounts shown are in billions of current dollars. Foreign-owned bills are those held in custody by the Federal Reserve Banks for foreign official and international accounts, as reported in the Federal Reserve's release H4.1. All figures are for December of the designated year, except those for the federa deficit, which apply to the October $1-$ September 30 fiscal year.

during this period. Moreover, these respective movements reinforced one another so as to produce the quantity ratio's rapid rise from 1987 through mid-1989 and even more rapid decline thereafter (see again the bottom panel of figure 2). Aggregate net issuance of commercial paper was especially large during 1988 and the first half of 1989, then slowed until about the end of the recession in early 1991, and then ceased altogether for the next two years. Net issuance of bank CDs was likewise strong from 1987 through mid-1989, but then became negative not just through the recession but over the next two years as well. These developments presumably reflected some combination of the 1980s' corporate leverage movement and its aftermath, the weakened capital positions of many commercial banks, the more aggressive posture of regulators in classifying nonperforming loans and enforcing capital requirements, and the forced consolidation (and in many cases liquidation) of the thrift industry-all of which by now are familiar stories-in addition, of course, to the influence of the business cycle itself. $^{18}$

By contrast, net issuance of Treasury bills was approximately zero on average from year-end 1986 through mid1989-just when issuance of commercial paper and bank CDs was so strong - and then became unusually large just as issuance of paper and CDs turned negative. As table 1 shows, this pattern of bill issuance reflected a combination of U.S. fiscal policy, the Treasury's debt management policy, and foreign central banks' exchange rate interventions (again together with the business cycle). The U.S. Government's budget deficit narrowed from $\$ 221$ billion in the 1986 fiscal year to $\$ 150$ billion in fiscal 1987, and then remained at about that level for the next two years before widening to $\$ 221$ billion in 1990 (and on to $\$ 270$ billion in 1991). The Treasury chose to maintain approximately its normal schedule of offerings of notes and bonds throughout this period, however, and so the quantity of bills outstanding

\footnotetext{
18 The role of bank capital constraints in restricting bank portfolio expansion is distinct from the role of monetary policy operating through the reserves market; see Friedman and Kuttner (1993b). A small part of the decline in CDs outstanding from 1989 on was also probably due to the development of markets for medium-term notes issued by bank holding companies and "bank notes" issued directly by banks; see Crabbe (1993).
}

first shrank and then expanded. A typical weekly auction of bills in 1986 featured $\$ 15.0$ billion of new 13- and 26-week bills offered against $\$ 14.4$ billion of maturing bills. In 1987 the typical auction offered only $\$ 13.0$ billion of new bills against $\$ 13.5$ billion maturing. By fiscal 1990 the typical auction was up to $\$ 16.0$ billion of new bills against $\$ 13.8$ billion maturing. Further, just when net bill issuance was already negative, in 1987, foreign central banks were intervening heavily in the exchange markets in support of the dollar, thereby increasing their holdings of U.S. Treasury bills and correspondingly reducing the market supply. ${ }^{19}$

The individual movement of each of these three asset quantities therefore contributed to increasing the ratio of commercial paper and bank CDs to Treasury bills from 1987 through early 1989, and then to reducing that ratio from mid-1989 on. To the extent that these observed movements in the relevant quantities represent independent changes in asset supplies (that is, changes in the composition of the "market portfolio"), while investors consider paper and CDs to be only imperfect substitutes for bills, standard portfolio theory predicts that they would affect the marketclearing expected returns on paper and CDs relative to bills. Specifically, from 1987 through early 1989 the larger relative quantity of paper and CDs would have increased the paper (and CD) rate relative to the bill rate, while from mid-1989 on the effect would have been just the opposite.

The vector autoregression described in section III provides one estimate of the importance of these asset quantity movements in accounting for the historically atypical movement of the paper-bill spread during this period. The results shown in the bottom panel of figure 3 indicate that changing asset quantities, summarized here in the form of the relevant ratio, indeed accounted for a major part of the movement of the paper-bill spread.

A key question in any such analysis is the extent to which these asset quantity movements reflect independent movement of asset supplies-in this case due to factors like corporate leveraging and deleveraging, bank capital constraints, Treasury debt management, and so on-as opposed to actions taken by borrowers in response to market forces, including interest rates themselves. It is therefore important for this purpose that the orthogonalization of the vector autoregression underlying figures 2 and 3 orders the asset quantity ratio after not only output and prices but also the level of interest rates (here the federal funds rate). Hence the innovations plotted in the bottom panel of figure 2 , and the effects of those innovations on the paper-bill spread shown in the bottom panel of figure 3, do represent movements in the asset quantity ratio due to factors other than either the business cycle or monetary policy. (As is to be expected, the relevant impulse response shows that tighter monetary

\footnotetext{
${ }^{19}$ Data on the outstanding quantity of bills shown in table 1 , used in the empirical work presented here, do not adjust for the effect of purchases by foreign central banks.
} 
policy causes the quantity of paper and CDs to increase relative to bills outstanding. ${ }^{20}$

By contrast, the ordering of variables in the orthogonalization underlying figures 2 and 3 implies that corporations' reliance on commercial paper and banks' issuance of CDs do not respond, within the month, to fluctuations in the paper rate (and implicitly the $\mathrm{CD}$ rate) relative to the bill rate, and there is no reason to suppose that this restriction is strictly true. Fully separating out the truly independent element in asset supplies, as opposed to supply responses to market prices set in part by asset demand behavior, would require a structural supply-demand model specifying the behavior of borrowers and lenders together with the resulting marketclearing equilibrium, and such a model lies well beyond the scope of this paper. ${ }^{21}$ It is therefore reassuring that variance decompositions of the same vector autoregression used in section III, but orthogonalized with the quantity ratio ordered after the paper-bill spread so that issuance of paper and CDs can respond to relative interest rates within the month, also produces asset quantity ratio innovations and effects of those innovations on the paper-bill spread that are highly similar to the series shown in figures 2 and 3 , respectively. In particular, in this alternate set of results the cumulative contribution to the spread due to quantity ratio innovations rose from 2 basis points in early 1987 to 21 basis points at mid-1988, and then declined to 3 basis points by late 1989 and on to -19 basis points by the beginning of 1991.

These alternate results reinforce the conclusion, from the bottom panel of figure 3 , that a large part of the historically unusual movement of the paper-bill spread in the few years preceding the 1990-1991 recession was indeed attributable to independent movements of the relevant asset quantities.

\section{Have Paper and Bills Become Closer Substitutes?}

The focus on relative asset quantities in the analysis reported in sections III and IV makes sense only if commercial paper and Treasury bills are imperfect substitutes in investors' portfolios. When two or more assets are imperfect substitutes, changes in their respective shares in the market portfolio lead in general to changes in their relative marketclearing expected returns. By contrast, expected returns on assets that are perfect substitutes are always identical, regardless of their respective outstanding quantities. (Even if the two assets bear differing nonpecuniary returns, their respective expected pecuniary returns will differ by a constant spread, or by a spread that changes with variations in investors' valuation of the nonpecuniary returns, but in any case not with changes in their respective quantities.)

In contrast to this paper's focus on relative asset quantity movements as a key element in the paper-bill spread's

\footnotetext{
${ }^{20}$ Friedman and Kuttner (1993b), using a more disaggregated system, found that tigher monetary policy leads to both more paper issuance and more CD issuance.

${ }^{21}$ See Friedman and Roley (1977) for a description and survey of such models.
}

failure to anticipate the 1990-1991 recession, some researchers have suggested that movements in the spread have lost their predictive power over time as evolution of the U.S. financial markets has rendered commercial paper and Treasury bills if not perfect then at least much closer substitutes. ${ }^{22}$ As figure 1 shows, the average spread between the paper rate and the bill rate has not become systematically smaller in recent years. Even the fairly narrow average spread that prevailed after the 1990-1991 recession ended was not atypical compared to prior nonrecession periods. Evidence of increasing substitutability between paper and bills would therefore have to consist of a diminished relationship between the movements of the spread and the movements of the corresponding asset quantities.

One of the equations in the six-equation vector autoregression described in section III-in particular, the equation for the paper-bill spread-already provides a vehicle for testing whether the connection between relative asset quantities and relative interest rates has weakened in recent years. Given the ordering of variables, which places the paper-bill spread last, the recursive orthogonalization procedure applied to the vector autoregression system is equivalent to including in the spread equation contemporaneous as well as lagged values of each of the other five variables, including in particular the asset quantity ratio. Estimated over the entire January 1976 through September 1996 sample, the sum of the coefficients on the quantity ratio terms is 1.58 (with $t$-statistic 3.5), implying that a permanent $1 \%$ increase in the quantity of paper and CDs, relative to the broader quantity also including bills, widens the paper-bill spread by between 1 and 2 basis points.

Increasing substitutability of paper (and CDs) with bills would imply a smaller value of this coefficient sum during the latter part of the sample, but there is no evidence of such a change. In an augmented version of the same equation, including additional terms so that each of the contemporaneous or lagged quantity ratio terms is also multiplied by a dummy variable equal to zero before January 1987 and unity thereafter, the sum of the coefficients on these interaction terms is actually positive (0.13) and statistically significant at the 10\% level ( $t$-statistic 1.64). If anything, therefore, the evidence points toward slightly diminished substitutability of paper and CDs for bills in the latter half of the sample.

The results presented in table 2 apply the same test procedure to three additional forms of the equation for the paper-bill spread. First, row (1) shows ordinary leastsquares estimates for a somewhat richer specification of the basic reduced-form spread equation, but with a more parsimonious lag structure. Here the simple asset quantity ratio is separated into the corresponding contemporaneous net asset flows, scaled by the lagged total quantity of asset stocks outstanding, and the lagged asset quantity ratio itself, and the flow issuance of paper and CDs is distinguished from the flow issuance of bills. Other variables from the

\footnotetext{
${ }^{22}$ See again Kashyap et al. (1993) and Thoma and Gray (1994).
} 
TABLE 2.-Tests FOR PARAMETER INSTABILITY ${ }^{\mathrm{a}}$

\begin{tabular}{|c|c|c|c|c|c|c|c|c|c|c|c|c|c|c|c|}
\hline & \multirow{3}{*}{$\begin{array}{l}\text { Paper } \\
+ \text { CD } \\
\text { Flow }\end{array}$} & \multirow{3}{*}{$\begin{array}{l}\text { Bill } \\
\text { Flow }\end{array}$} & \multirow{3}{*}{$\begin{array}{c}\text { Lagged } \\
\text { Paper } \\
+ \text { CD } \\
\text { Ratio }\end{array}$} & \multirow{3}{*}{$\begin{array}{c}\text { P2-P1 } \\
\text { Differential }\end{array}$} & \multirow{3}{*}{$\begin{array}{l}\text { Inflation } \\
\text { Change }\end{array}$} & & & \multirow{3}{*}{$\begin{array}{l}\text { Lagged } \\
\text { Paper- } \\
\text { Bill } \\
\text { Spread }\end{array}$} & \multirow{2}{*}{\multicolumn{2}{|c|}{ Paper Rate }} & \multicolumn{3}{|c|}{ Post-1986 Dummy $\times$} & \multirow{3}{*}{$\begin{array}{c}\text { Joint } \\
\text { Significance }\end{array}$} & \multirow[b]{3}{*}{$\bar{R}^{2}$} \\
\hline & & & & & & \multicolumn{2}{|c|}{ Fed Funds Rate } & & & & & Paper & Paper & & \\
\hline & & & & & & Current & Lagged & & Current & Lagged & Flow & Flow & Ratio & & \\
\hline (1) & $\begin{array}{c}0.46 \\
(0.12)\end{array}$ & $\begin{array}{r}-0.24 \\
(0.10)\end{array}$ & $\begin{array}{c}1.16 \\
(0.30)\end{array}$ & $\begin{array}{c}0.19 \\
(0.07)\end{array}$ & $\begin{array}{r}-0.36 \\
(0.16)\end{array}$ & $\begin{array}{c}0.13 \\
(0.02)\end{array}$ & $\begin{array}{r}-0.13 \\
(0.02)\end{array}$ & $\begin{array}{c}0.62 \\
(0.06)\end{array}$ & - & - & - & - & - & - & 0.83 \\
\hline (2) & $\begin{array}{c}0.50 \\
(0.14)\end{array}$ & $\begin{array}{r}-0.26 \\
(0.15)\end{array}$ & $\begin{array}{c}0.90 \\
(0.33)\end{array}$ & $\begin{array}{c}0.22 \\
(0.08)\end{array}$ & $\begin{array}{r}-0.33 \\
(0.15)\end{array}$ & $\begin{array}{c}0.13 \\
(0.02)\end{array}$ & $\begin{array}{r}-0.12 \\
(0.02)\end{array}$ & $\begin{array}{c}0.57 \\
(0.06)\end{array}$ & - & - & $\begin{array}{c}0.04 \\
(0.18)\end{array}$ & $\begin{array}{c}-0.01 \\
(0.18)\end{array}$ & $\begin{array}{c}0.18 \\
(0.07)\end{array}$ & 0.08 & 0.84 \\
\hline (3) & $\begin{array}{c}2.12 \\
(0.52)\end{array}$ & $\begin{array}{r}-0.20 \\
(0.11)\end{array}$ & $\begin{array}{c}2.04 \\
(0.54)\end{array}$ & $\begin{array}{c}0.42 \\
(0.13)\end{array}$ & $\begin{array}{c}-0.31 \\
(0.15)\end{array}$ & - & - & $\begin{array}{c}0.32 \\
(0.14)\end{array}$ & - & - & - & - & - & - & 0.70 \\
\hline (4) & $\begin{array}{c}2.33 \\
(0.53)\end{array}$ & $\begin{array}{r}-0.28 \\
(0.18)\end{array}$ & $\begin{array}{l}1.94 \\
(0.52)\end{array}$ & $\begin{array}{c}0.59 \\
(0.12)\end{array}$ & $\begin{array}{r}-0.25 \\
(0.14)\end{array}$ & - & - & $\begin{array}{c}0.21 \\
(0.12)\end{array}$ & - & - & $\begin{array}{c}0.14 \\
(0.23)\end{array}$ & $\begin{array}{c}0.54 \\
(0.62)\end{array}$ & $\begin{array}{c}0.36 \\
(0.13)\end{array}$ & 0.02 & 0.67 \\
\hline (5) & $\begin{array}{c}2.62 \\
(1.57)\end{array}$ & $\begin{array}{c}-0.25 \\
(0.12)\end{array}$ & $\begin{array}{c}2.77 \\
(0.33)\end{array}$ & $\begin{array}{c}0.63 \\
(0.34)\end{array}$ & $\begin{array}{r}-0.28 \\
(0.15)\end{array}$ & - & - & $\begin{array}{c}0.40 \\
(0.25)\end{array}$ & $\begin{array}{c}0.07 \\
(0.06)\end{array}$ & $\begin{array}{c}-0.11 \\
(0.03)\end{array}$ & - & - & - & - & 0.67 \\
\hline (6) & $\begin{array}{c}1.53 \\
(1.08)\end{array}$ & $\begin{array}{r}-0.37 \\
(0.14)\end{array}$ & $\begin{array}{c}1.54 \\
(0.85)\end{array}$ & $\begin{array}{c}0.46 \\
(0.21)\end{array}$ & $\begin{array}{r}-0.25 \\
(0.12)\end{array}$ & - & - & $\begin{array}{c}0.45 \\
(0.14)\end{array}$ & $\begin{array}{c}0.11 \\
(0.04)\end{array}$ & $\begin{array}{r}-0.11 \\
(0.03)\end{array}$ & $\begin{array}{c}0.20 \\
(0.18)\end{array}$ & $\begin{array}{c}0.41 \\
(0.55)\end{array}$ & $\begin{array}{c}0.20 \\
(0.12)\end{array}$ & 0.10 & 0.79 \\
\hline
\end{tabular}

Notes: The regressions are estimated on monthly data from January 1975 through September 1996. All regressions also include a constant and linear trend. Both flow variables are annualized and normalized by the lagged stock of commercial paper + CDs + Treasury bills. The spread is expressed in percentage terms. Numbers in parentheses are standard errors, corrected for heteroskedasticity and 12 th-order serial correlation. Equations (3) and (4) are estimated via two-stage least squares, using one lag of the federal funds rate as an instrument for the flow of paper + CDs. Equations (5) and (6) are estimated via two-stage least squares, using the lagged ratio of nonborrowed to lagged total reserves as an instrument for the flow of paper + CDs.

${ }^{\text {a }}$ Dependent variable is the 6-month paper-bill spread.

spread equation in the vector autoregression are included or excluded according to statistical significance at the 0.05 level. (The equation also includes an intercept and a linear time trend, both of which are statistically significant; the trend is small but positive.) The numbers shown in parentheses are robust $t$-statistics corrected for heteroskedasticity and twelfth-order moving-average serial correlation.

The results for the asset quantity variables shown in row (1) correspond to what standard portfolio theory implies when assets are imperfect substitutes. An increase in the net issuance of paper and CDs by $1 \%$, relative to the outstanding stock of paper, CDs, and bills, widens the paper-bill spread in the same month by about one-half basis point. A $1 \%$ increase in the net issuance of bills affects the paper-bill spread by about half as much, in the opposite direction. A permanent $1 \%$ increase in the ratio of paper and CDs to the broader quantity also including bills widens the spread by about 3 basis points $[1.16 /(1-0.62)]$. The coefficients on all three terms are significant at the 0.05 level or better.

Row (2) shows the results of estimating an expanded equation in which each of the three asset quantity variables also appears multiplied by the dummy variable, allowing a break at January 1987. There is no statistically significant evidence of such a break for either asset flow term, but there is for the ratio of asset stocks. Here again, however, it is in the direction indicating a larger effect of relative asset quantities on relative interest rates, and hence diminished substitutability of paper and CDs for bills. Here the effect on the spread due to a permanent $1 \%$ change in the quantity ratio is 2.51 basis points from 1987 on $[(0.90+0.18) /$ ( $1-0.57)$ ], compared to 2.09 basis points in the earlier part of the sample.

The remaining rows in table 2 present further results that refine the test for changing substitutability of paper and CDs for bills, in that they take account of effects of interest rates on asset supply behavior. Doing so is important because statements about substitutability among any group of assets are inherently statements about investors' asset demand behavior. To the extent that issuers' asset supply behavior also depends on interest rates, and that changing asset supplies in turn feed back to affect the market-clearing structure of interest rates, reduced-form equations like those in the table's first two rows (or the spread equation from the vector autoregression) will misrepresent the effect on interest rates due to independent asset supply changes, and hence likewise misrepresent the underlying asset substitutabilities in investors' portfolios.

The pair of equations shown in rows (3) and (4) take account of interest rate effects on private asset supplies by using two-stage least squares with the lagged change in the federal funds rate as an instrument for the net issuance of commercial paper and CDs. (The Treasury's issuance of bills is again taken to be nonresponsive to interest rates and therefore not instrumented.) The key identifying assumption implicit in this structure is that interest rate movements affect the paper-bill spread only to the extent that they influence corporations' issuance of paper or banks' issuance of CDs. Especially since the equation also includes the P2-P1 quality differential as a measure of perceived default risk, the assumption that interest rate levels do not directly affect investors' relative demand for paper and CDs versus bills is not implausible.

The results shown in row (3) are similar to the ordinary least-squares estimates in row (1), but the effect on the spread attributed to independent changes in the flow of paper and CDs is now much larger-as is to be expected once the simultaneity bias is corrected. Here a $1 \%$ increase in the net issuance of paper and CDs (again relative to the broader 
asset quantity) widens the paper-bill spread in the same month by more than 2 basis points, and the permanent effect of a $1 \%$ increase in the ratio of outstanding paper and CDs to the broader total quantity is 3 basis points. More to the point of the question at issue in this paper, the evidence again indicates a change (here significant at the 0.01 level) in the coefficient on the asset quantity ratio in 1987, but again it is in the direction indicating not greater substitutability of paper and CDs for bills but less.

Finally, the regressions underlying rows (5) and (6) in table 2 also include the current and lagged commercial paper rate to allow for the possibility-due to differential statelevel taxation, for example - that the level of interest rates might directly affect investors' demand for paper and CDs versus bills. Here the instrument for the net issuance of paper and CDs, in the two-stage estimation, is the lagged ratio of nonborrowed reserves to total reserves. ${ }^{23}$ The results are broadly similar to those shown in the two rows immediately above, although the significance level of several of the key coefficients differs. (Most obviously, the estimated coefficient on the instrumented paper-plus-CD flow is larger here than above, but not statistically significant.) Yet again, the only evidence of a break at 1987-albeit significant here only at the 0.10 level-is for the asset quantity ratio, and yet again the change is in the direction implying reduced substitutability.

In short, these results provide no evidence whatever to support the suggestion that in recent years commercial paper and Treasury bills have become closer substitutes in investors' portfolios.

\section{Conclusions and Implications}

The empirical work reported in this paper supports two different (but not mutually exclusive) explanations for the paper-bill spread's failure to anticipate the 1990-1991 recession, but does not support two others: First, there is evidence that the 1990-1991 recession was unusual in not having been brought about by tight monetary policy. To the extent that at least part of the spread's systematic relationship to prior business cycle fluctuations reflected its role as an indicator of monetary policy, there was therefore less reason to expect the spread to anticipate this particular recession. Second, there is also evidence that movements of the spread during the several years prior to the 1990-1991 recession were heavily influenced by changes in the outstanding quantities of commercial paper, bank CDs, and Treasury bills that occurred for reasons unrelated to the business cycle.

By contrast, there is no evidence that changing market perceptions of default risk had much influence on the spread's unusual movements during this period. There is also no evidence that commercial paper and Treasury bills have become closer (much less perfect) substitutes in recent

\footnotetext{
${ }^{23}$ See Strongin (1995), and the references cited there, on the use of the nonborrowed to total reserves ratio as a measure of monetary policy.
}

years so that the spread between their respective interest rates is now mostly "noise" that would not be expected to exhibit systematic relationships to changes in their respective quantities (and, via that route, to business cycle fluctuations).

The finding that asset quantity movements in particular heavily influenced the paper-bill spread during the period under study here highlights the burdens associated with the use of relative interest rate relationships as business cycle indicators. Standard portfolio theory shows that, in general, changes in asset quantities should affect interest rate spreads. The evidence assembled in this paper shows that, at least in the case of commercial paper and Treasury bills, changes in asset quantities $d o$ affect interest rate spreads. ${ }^{24}$ Some changes in asset quantities occur for reasons related to the business cycle-after all, that is part of what gives the spread its indicator properties in the first place-while others do not, but changes of both kinds affect the corresponding spreads. Naively using any particular interest rate spread to predict business fluctuations, without being sensitive to the possibility of idiosyncratic movements in the corresponding asset quantities and hence making due allowance for those movements when they occur, can therefore be a source of mistakes. In this respect, at least, interest rate spreads plainly have much in common with other familiar classes of business cycle indicators.

\section{REFERENCES}

Bernanke, Ben S., "On the Predictive Power of Interest Rates and Interest Rate Spreads," New England Economic Review (Nov./Dec. 1990), $51-68$.

Bernanke, Ben S., and Alan S. Blinder, "The Federal Funds Rate and the Channels of Monetary Transmission," American Economic Review 82 (Sept. 1992), 901-921.

Calomiris, Charles W., Charles P. Himmelberg, and Paul Wachtel, "Commercial Paper and the Business Cycle: A Microeconomic Perspective," Mimeo, National Bureau of Economic Research (1994).

Christiano, Laurence J., Martin Eichenbaum, and Charles Evans, "The Effects of Monetary Policy Shocks: Some Evidence from the Flow of Funds," this Review 78 (Feb. 1996), 16-34.

Cook, Timothy, "Determinants of the Spread between Treasury Bill and Private Sector Money Market Rates," Journal of Economics and Business 33 (Spring 1981), 177-187.

Crabbe, Leland, "Anatomy of the Medium-Term Note Market," Federal Reserve Bulletin 79 (Aug. 1993), 751-768.

Davis, E. P., and S. G. B. Henry, "An Aggregate VAR Model with Financial Spreads," Mimeo, Bank of England (1991).

Estrella, Arturo, and Frederic S. Mishkin, "Predicting U.S. Recessions: Financial Variables as Leading Indicators," Mimeo, Federal Re-

\footnotetext{
${ }^{24}$ Moreover, although each historical episode of course exhibits its own features, the idiosyncratic asset quantity changes of the late 1980s analyzed here hardly constitute a unique experience. For example, after increasing almost continuously from 1990 through 1995, the quantity of Treasury bills outstanding declined from a peak of $\$ 812$ billion in early 1996 to $\$ 704$ billion at midyear 1997 (the latest available data). By contrast, the respective quantities of commercial paper and bank CDs continued to increase in 1996 and 1997 at about the same rates as in the previous several years. Not surprisingly, this most recent reversal in the issuance pattern of Treasury bills was again associated with a widening of the paper-bill spread, albeit to not nearly so great an extent as in 1987. (This footnote was inserted after the paper was accepted for publication, just as this issue of the REVIEW was about to go to press.)
} 
serve Bank of New York; revision of NBER Working Paper 5379 (1996).

Ferderer, J. Peter, Steven C. Vogt, and Ravi Chahil, "Increasing Liquidity and the Declining Informational Content of the Paper-Bill Spread," Journal of Economics and Business (1998).

Friedman, Benjamin M., "Does Monetary Policy Affect Real Economic Activity? Why Do We Still Ask This Question?" in H. Siebert (ed.), Monetary Policy in an Integrated World Economy (Tübingen, Germany: J. C. B. Mohr, 1996).

Friedman, Benjamin M., and Kenneth N. Kuttner, "Money, Income, Prices, and Interest Rates," American Economic Review 82 (June 1992), 472-492.

"Why Does the Paper-Bill Spread Predict Real Economic Activity?" in James Stock and Mark W. Watson (eds.), Business Cycles, Indicators, and Forecasting (Chicago: University of Chicago Press, 1993a).

"Economic Activity and the Short-Term Credit Markets: An Analysis of Prices and Quantities," Brookings Papers on Economic Activity, no. 2 (1993b), 193-283.

Friedman, Benjamin M., and V. Vance Roley, "Structural Models of Interest Rate Determination in the Corporate and Government Bond Markets," American Statistical Association Proceedings of the Business and Economics Statistics Section, pt. II (1977) 142-151.

Friedman, Milton, and Anna J. Schwartz, A Monetary History of the United States, 1867-1960 (Princeton, NJ: Princeton University Press, 1963).

Huh, Chan, "Asymmetry in the Relationship between Output and Interest Rates," Mimeo, Federal Reserve Bank of San Francisco (1993).

Kashyap, Anil K., Jeremy C. Stein, and David W. Wilcox, "Monetary Policy and Credit Conditions: Evidence from the Composition of External Finance," American Economic Review 83 (June 1993), 78-98.
Kuttner, Kenneth N., "Monetary Policy and External Finance: Interpreting the Behavior of Financial Flows and Interest Rate Spreads," Mimeo, Federal Reserve Bank of Chicago (1992).

Lahiri, Kajal, and Jiazhuo G. Wang, "Interest Rate Spreads as Predictors of Business Cycles," Mimeo, State University of New York, Albany (1994).

Miyao, Ryuzo, Essays in Money and Output, Ph.D. Dissertation, Harvard University (1994).

Perry, George L., and Charles L. Schultze, "Was This Recession Different? Are They All Different?" Brookings Papers on Economic Activity no. 1 (1993), 145-211.

Poole, William, "Monetary Aggregates Targeting in a Low-Inflation Economy," in J. C. Fuhrer (ed.), Goals, Guidelines, and Constraints Facing Monetary Policymakers (Boston: Federal Reserve Bank of Boston, 1994).

Prescott, Edward, "Theory ahead of Business Cycle Measurement," Federal Reserve Bank of Minneapolis Quarterly Review (Fall 1986), 9-22.

Romer, Christina D., and David H. Romer, "Does Monetary Policy Matter? A New Test in the Spirit of Friedman and Schwartz," NBER Macroeconomics Annual (Cambridge, MA: MIT Press, 1989).

Sims, Christopher A., "Interpreting the Macroeconomic Time Series Facts: The Effects of Monetary Policy," European Economic Review 36:5 (1992), 975-1000.

Stock, James, and Mark W. Watson, "New Indexes of Coincident and Leading Economic Indicators," NBER Macroeconomics Annual (1989), 351-394.

Strongin, Steven H., "The Identification of Monetary Policy Disturbances," Journal of Monetary Economics 35 (June 1995), 463-497.

Thoma, Mark A., and JoAnna Gray, "On Leading Indicators: Is There a Leading Contender?" Mimeo, University of Oregon (1994). 
This article has been cited by:

1. Heather M. Anderson, George Athanasopoulos, Farshid Vahid. 2007. Nonlinear autoregressive leading indicator models of output in G-7 countries. Journal of Applied Econometrics 22:1, 63-87. [CrossRef]

2. Marcelle Chauvet, Simon Potter. 2005. Forecasting recessions using the yield curve. Journal of Forecasting 24:2, 77-103. [CrossRef] 